\title{
Moult records for tropical bird species trapped in Angola
}

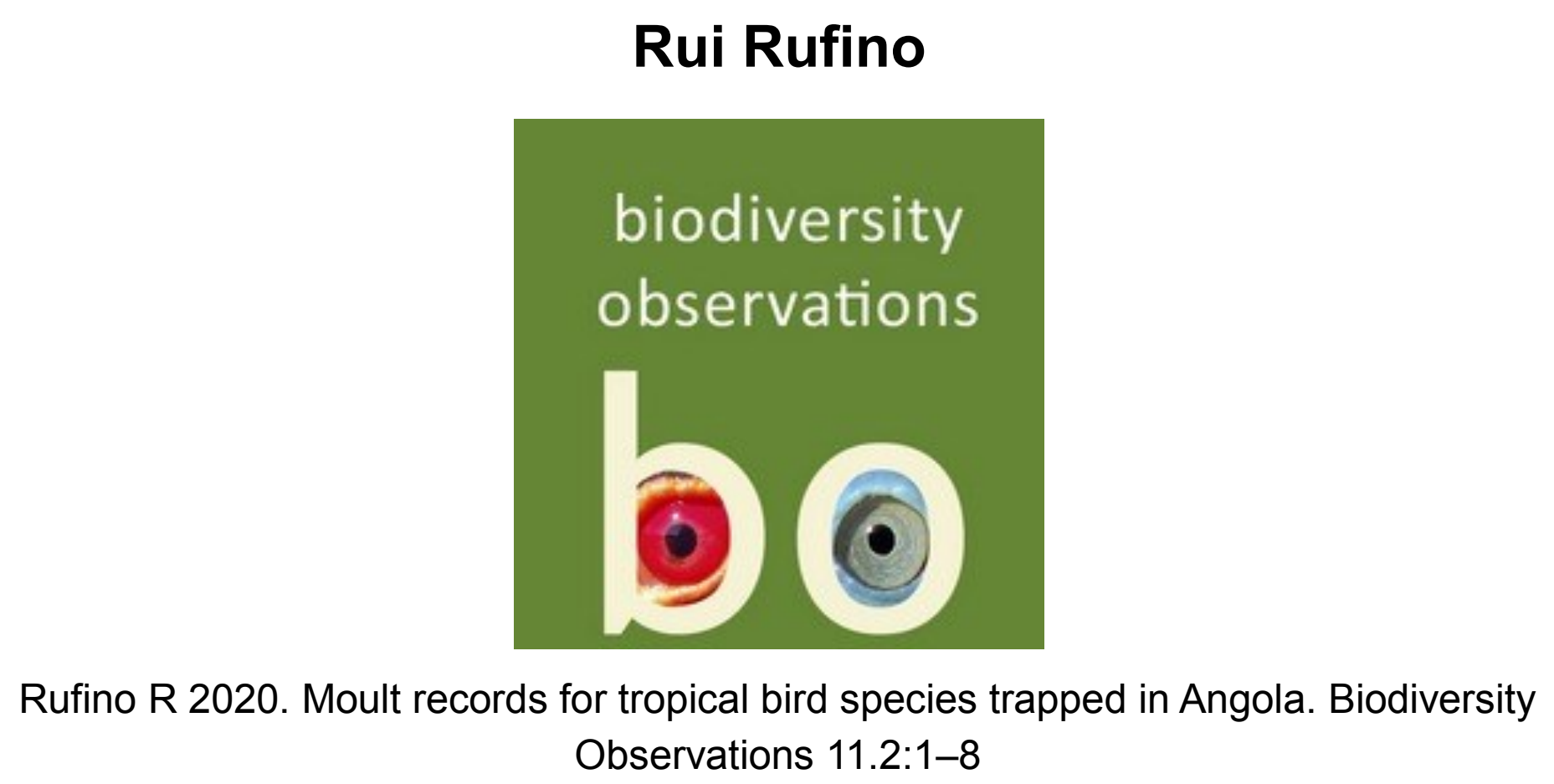

Angola, Bird ringing, primary moult 


\section{Ornithology}

\section{Moult records for tropical bird species trapped in Angola}

Rui Rufino, Mãe d'água, Lda. - Rua Marcelino Mesquita 11, Loja 4, Esc. 1, 1495-766 Dafundo, Portugal

Email: rui.rufino@maedagua.pt

\section{Abstract}

Between 21 and 27 July 2015 a total of 43 birds of 15 species were caught with mist nets at Kissikina, Malange, Angola. Thirty-two of those, of 11 species, were moulting primaries and their moult was recorded. In this note, I present the data collected hoping to add some information on the moult patterns of these species in this part of the world.

\section{Introduction}

Several papers on the moult of southern Africa birds have been published with data collected in different countries, especially South Africa (Craig, 1983). However no detailed information on moult and its timing could be found for Angola.

In 2015 as part of monitoring studies carried out in the province of Malange, Angola, a number of birds were caught for identification. Because many of them were moulting primaries we kept records in order to make this information available to those who are studying moult in this region of the world.

\section{Materials and methods}

The birds were caught at Kissikina, Malange, Angola (947'43"S; $15^{\circ}$ $\left.14^{\prime} 27^{\prime \prime} E\right)$, about $250 \mathrm{~km}$ east-south-east of Luanda. We used mist-nets which were set up on the edge of an abandoned farming area near the River Kwanza between 21 and 27 July 2015. (Figures 1 and 2).

A total of 43 birds of 15 species were caught of which 32 birds of 11 species were undergoing primary moult (Appendices 1). Moult was recorded following the standard system used by Ginn \& Melville (1983). This system scores the moult status from 0 (old feather) to 5 (new feather fully grown). Absent feathers were considered as stage 1.

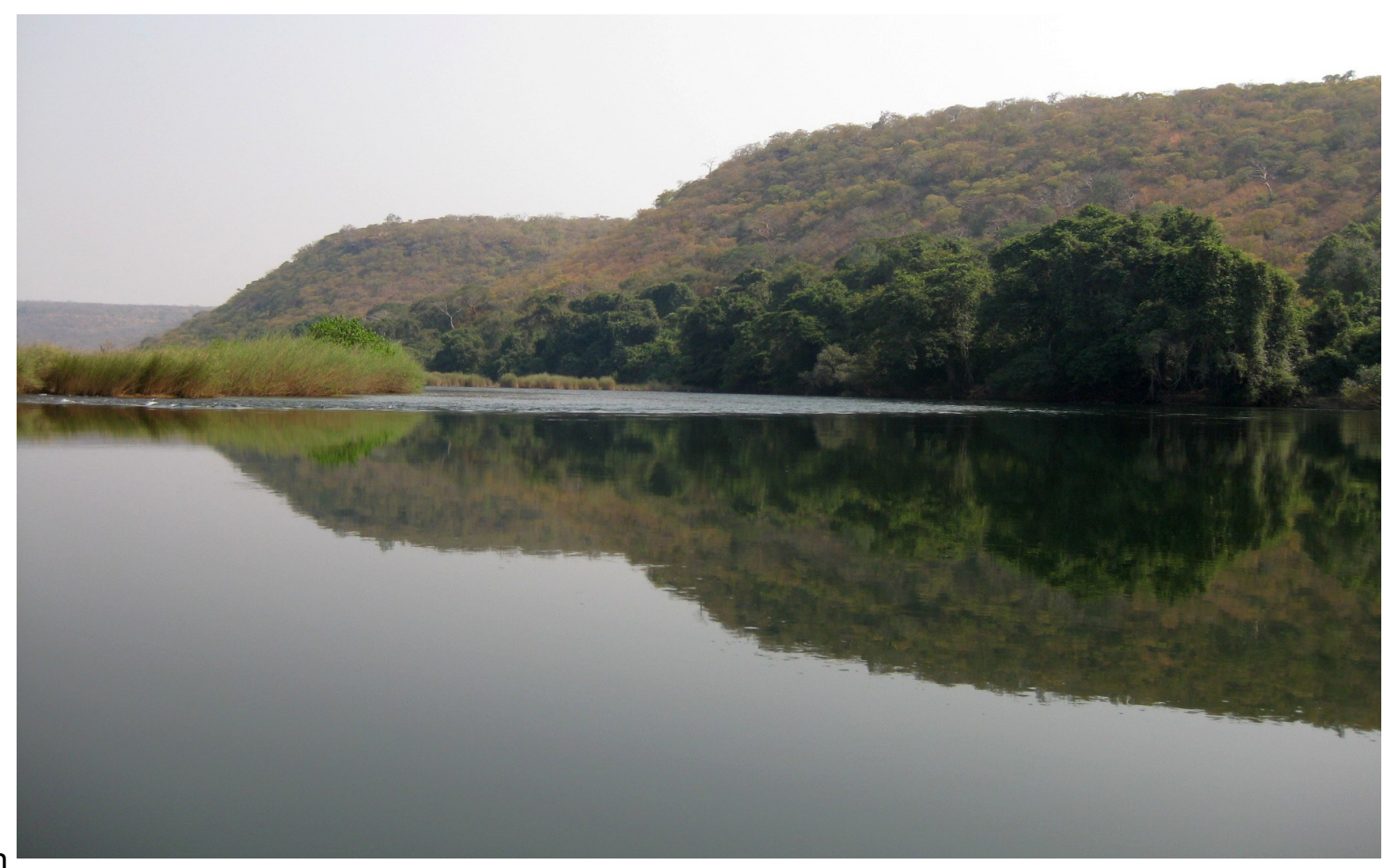

Figure 1. View of the Kwanza River, north of the ringing area at Kissikina, Malange, Angola. 
For names and systematic order we followed Mills \& Melo (2013) who in turn had followed version 3.1 of the International Ornithological Committee's recommended names (Gill et al. 2012).

\section{Results and discussion}

Detailed results for the moult of each bird are given in Table 1. The ordering of species in the table is replicated below.

Emerald-spotted Wood-Dove Turtur chalcospilos - Two birds were caught. Both were in active moult. One bird, possibly an adult, already had five new feathers followed by a stage 4, three old and a stage 1. The other bird, possibly a juvenile, was at the early stages of its moult with two stage 4 feathers followed by eight old. This dove clearly showed marked buff tips to the tertials (innermost secondaries). Apparently, there is a difference in moult timing between adults and first year birds as suggested by the data collected.

Blue-spotted Wood-Dove Turtur afer - The two birds caught were possibly in suspended moult. One of them was showing five new and five old feathers while the other showed the existence of two moult centres with three new feathers, followed by four old and another three new.

Red-backed Mousebird Colius castanotus - Five birds were caught, all of which were moulting. However, moult varied considerably from bird to bird. One bird was starting its moult showing one new feather, the following feather was at stage 3 and the remainder were all old. Two birds were a bit further on in their moult, one with seven new feathers followed by a stage 4 , a stage 1 and an old feather. The second had six new feathers followed by a stage 4 and three old. Finally, two birds showed two moult centres in the sequence. One had a sequence of two completely new feathers followed by three old, another two new, a stage 2 and another old. The other bird had five new feathers. then a stage 4, an old, a new, an old and a stage 4.

For Colius striatus, Moreau et al. (1948) suggested that "moult is irregular and proceeds indefinitely". Rowan (1967) analysed samples of C. striatus, C. indicus and C. colius from South Africa and noted that $80 \%$ of the $C$. striatus taken between November and April that were examined were moulting primaries but only $25 \%$ of the birds taken during the remaining months were in active moult. In C. colius moult seems to occur mostly between February and May (Moreau et al. 1948). Finally, for $C$. indicus these authors suggests that replacement of feathers is seasonal with most birds moulting between November and April. No information is given by these authors for $C$. castanotus.

The moult pattern of the birds caught in Angola in July suggests that moult takes place at least during a period of time covering the months

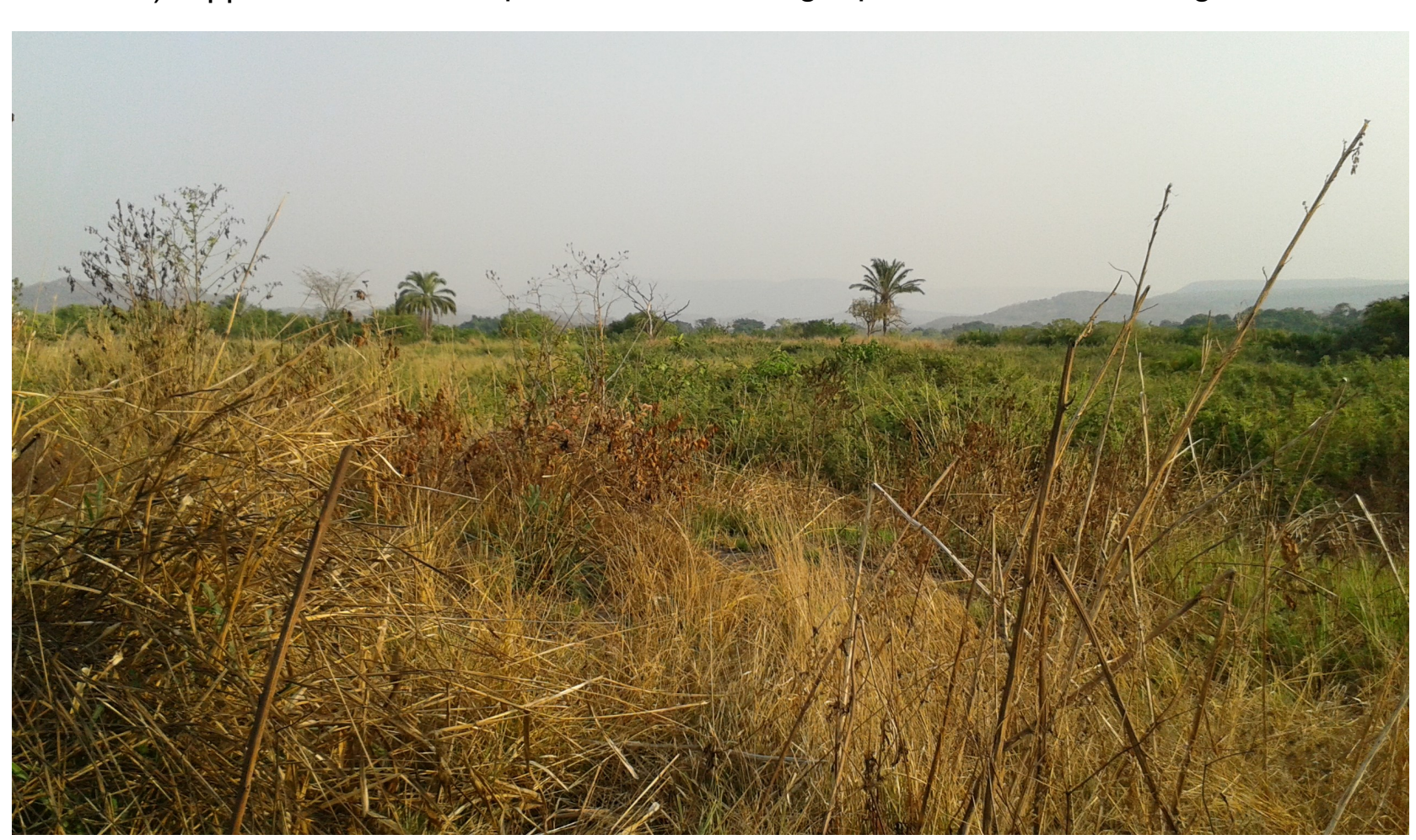

Figure 2. The habitat at the ringing site at Kissikina, Malange, Angola, in July 2015. 
Table 1. Primary moult protocols of 43 birds trapped at Kissikina, Malange, Angola. Dates are all in July 2015. The order of the feathers follows the standard moult sequence from the inner to the outer primaries.

\begin{tabular}{|c|c|c|c|c|}
\hline Date & Species & Age & Sex & Moult \\
\hline 24 & Turtur chalcospilos & Ad? & & $5^{5} 40^{3} 1$ \\
\hline 24 & Turtur chalcospilos & Juv & & $4^{2} 0^{8}$ \\
\hline 27 & Turtur afer & $\mathrm{Ad}$ & & $5^{5} 0^{5}$ \\
\hline 27 & Turtur afer & $\mathrm{Ad}$ & & $5^{3} 0^{4} 5^{3}$ \\
\hline 27 & Colius castanotus & & & $530^{8}$ \\
\hline 27 & Colius castanotus & & & $5^{2} 0^{3} 5^{2} 20^{2}$ \\
\hline 27 & Colius castanotus & & & $5^{7} 410$ \\
\hline 27 & Colius castanotus & & & $5^{5} 40504$ \\
\hline 27 & Colius castanotus & & & $5^{6} 40^{3}$ \\
\hline 23 & Dryoscopus cubla & & $F(?)$ & no active moult \\
\hline 22 & Pycnonotus tricolor & & & no active moult \\
\hline 22 & $\begin{array}{l}\text { Chlorocichla flavi- } \\
\text { ventris }\end{array}$ & & & no active moult \\
\hline 23 & $\begin{array}{l}\text { Chlorocichla flavi- } \\
\text { ventris }\end{array}$ & Ad (?) & & no active moult \\
\hline 23 & $\begin{array}{l}\text { Chlorocichla falken- } \\
\text { steinii }\end{array}$ & $\mathrm{Ad}$ & & $5^{5} 40^{4}$ \\
\hline 24 & $\begin{array}{l}\text { Psalidoprocne } \\
\text { pristoptera }\end{array}$ & $\operatorname{Ad}(?)$ & $M(?)$ & $5^{5} 430^{3}$ \\
\hline 24 & $\begin{array}{l}\text { Psalidoprocne } \\
\text { pristoptera }\end{array}$ & $\operatorname{Ad}(?)$ & $F(?)$ & $5^{4} 4^{3} 0^{3}$ \\
\hline 24 & Hirundo angolensis & $\mathrm{Ad}$ & & no active moult \\
\hline 24 & Hirundo angolensis & $\operatorname{Ad}(?)$ & & $5^{8} 41$ \\
\hline 22 & Iduna natalensis & $\operatorname{Ad}(?)$ & & $5^{9} 4$ \\
\hline 22 & Iduna natalensis & $\operatorname{Ad}(?)$ & & no active moult \\
\hline
\end{tabular}

\begin{tabular}{|c|c|c|c|c|}
\hline Date & Species & Age & Sex & Moult \\
\hline 21 & Cisticola bulliens & $\mathrm{Ad}$ & & $5^{7} 4^{3}$ \\
\hline 22 & Cisticola bulliens & $\mathrm{Ad}$ & & $5^{8} 4^{2}$ \\
\hline 22 & Ploceus ocularis & Juv (?) & & no active moult \\
\hline 22 & Ploceus ocularis & $\mathrm{Ad}$ & $F(?)$ & no active moult \\
\hline 22 & Ploceus ocularis & $\mathrm{Ad}$ & M & no active moult \\
\hline 21 & Pytilia melba & $\mathrm{Ad}$ & $M$ & $5^{2} 410^{6}$ \\
\hline 22 & Pytilia melba & Juv & & no active moult \\
\hline 22 & Pytilia melba & $\mathrm{Ad}$ & $M$ & $5^{2} 40^{7}$ \\
\hline 27 & Pytilia melba & $\mathrm{Ad}$ & $\mathrm{F}$ & $520^{8}$ \\
\hline 27 & Pytilia melba & $\mathrm{Ad}$ & $M$ & $5^{5} 430^{3}$ \\
\hline 22 & $\begin{array}{l}\text { Lagonosticta rhodo- } \\
\text { pareia }\end{array}$ & & M & $5430^{7}$ \\
\hline 22 & $\begin{array}{l}\text { Lagonosticta rhodo- } \\
\text { pareia }\end{array}$ & & $F(?)$ & $530^{8}$ \\
\hline 23 & $\begin{array}{l}\text { Lagonosticta rhodo- } \\
\text { pareia }\end{array}$ & $\mathrm{Ad}$ & $\mathrm{F}$ & $5^{3} 420^{4} 1$ \\
\hline 27 & $\begin{array}{l}\text { Lagonosticta rhodo- } \\
\text { pareia }\end{array}$ & $\operatorname{Ad}(?)$ & & $5^{3} 40^{6}$ \\
\hline 27 & $\begin{array}{l}\text { Lagonosticta rhodo- } \\
\text { pareia }\end{array}$ & & & $5^{2} 420^{6}$ \\
\hline 22 & Estrilda melpoda & $\operatorname{Ad}(?)$ & & $5^{6} 40^{3}$ \\
\hline 23 & Estrilda melpoda & (?) & & no active moult \\
\hline 23 & Estrilda melpoda & $\mathrm{Ad}$ & & $5^{5} 40^{4}$ \\
\hline 23 & Estrilda melpoda & $\mathrm{Ad}$ & & $5^{8} 40$ \\
\hline 23 & Estrilda melpoda & $\mathrm{Ad}$ & & $5^{6} 40^{3}$ \\
\hline 23 & Estrilda melpoda & $\mathrm{Ad}$ & & $5^{8} 40$ \\
\hline 23 & Estrilda melpoda & $\mathrm{Ad}$ & & $5^{7} 40^{2}$ \\
\hline 23 & Estrilda melpoda & $\mathrm{Ad}$ & & $5^{5} 40^{4}$ \\
\hline
\end{tabular}


of June to August, given the stage of moult in the birds caught. These data also suggest some irregularity in the moult of this species.

Regarding the sequence of the moult, Rowan (1967) drew attention to the fact that Moreau et al. (1948) had mentioned the irregularity of the moult in mousebirds but both Verheyen (1956) and Stresemann (1966) "describe the moult as descendant". The author states that in the South Africa specimens most birds (90\% of $C$. striatus and C. colius and $75 \%$ of $C$. indicus) show a regular moult pattern, from the inner to the outer, but that the remaining birds have a wide variety or irregularities. The moult observed in the five $C$. castanotus caught in Angola suggested that moult patterns are irregular and at least some of the birds undertake an eccentric moult and/or might suspend moult.

These findings are broadly supported by a study of the primary moult of the three species of mousebirds that occur in South Africa (Craig et al. 2014). This study confirmed that the mousebirds have an extended moult period, both as individuals and as populations. They concluded: "There is still a lot to learn about the annual cycle of South African mousebirds."

Black-backed Puffback Dryoscopus cubla - One bird was caught which did not show signs of moult. Its primary feathers showed a certain amount wear. Craig (1983) does not mention a period for the complete moult which adults undertake yearly. According to Verheyen (1953) the species does two complete moults a year but no date is given. The feather wear of the bird caught suggests that the bird had moulted some time previously.

Dark-capped Bulbul Pycnonotus tricolor - One bird was caught and it was not in active moult. The flight feathers were slightly worn. According to Craig (1983) in East Africa and Malawi the species seems to moult between December and July. In KwaZuluNatal and Eastern Cape moult was recorded from January to June. The feather wear of the birds caught in Angola during our monitoring work suggests that the bird had completed its moult recently. This corroborates the dates above mentioned.

Yellow-bellied Greenbul Chlorocichla flaviventris - Two birds were caught but none showed signs of recent moult. The tips of the primaries showed a certain amount of wear on both birds suggesting that moult will take place later in the season.

Falkenstein's Greenbul Chlorocichla falkensteinii - One bird was caught and it was half way through its moult. The first five primaries were new and were followed by a feather in stage 4 . The remaining feathers were old. The moult pattern found in this bird suggests a feather by feather moult sequence but this assumption will have to be confirmed by a more extensive set of data. According to Sekercioglu and Riley (2005) at the Kumbira forest, Gabela, Angola, not far from the site were the bird was caught, this species was breeding in January so the bird caught was probably undertaking a post-nuptial moult.

Black Saw-wing Psalidoprocne pristoptera - Two birds were caught, both in active moult (Figure 3). One bird, possibly a male, had five new feathers followed by a stage 4 , a stage 3 and three old. The other bird, possibly a female, had four new feathers followed by three

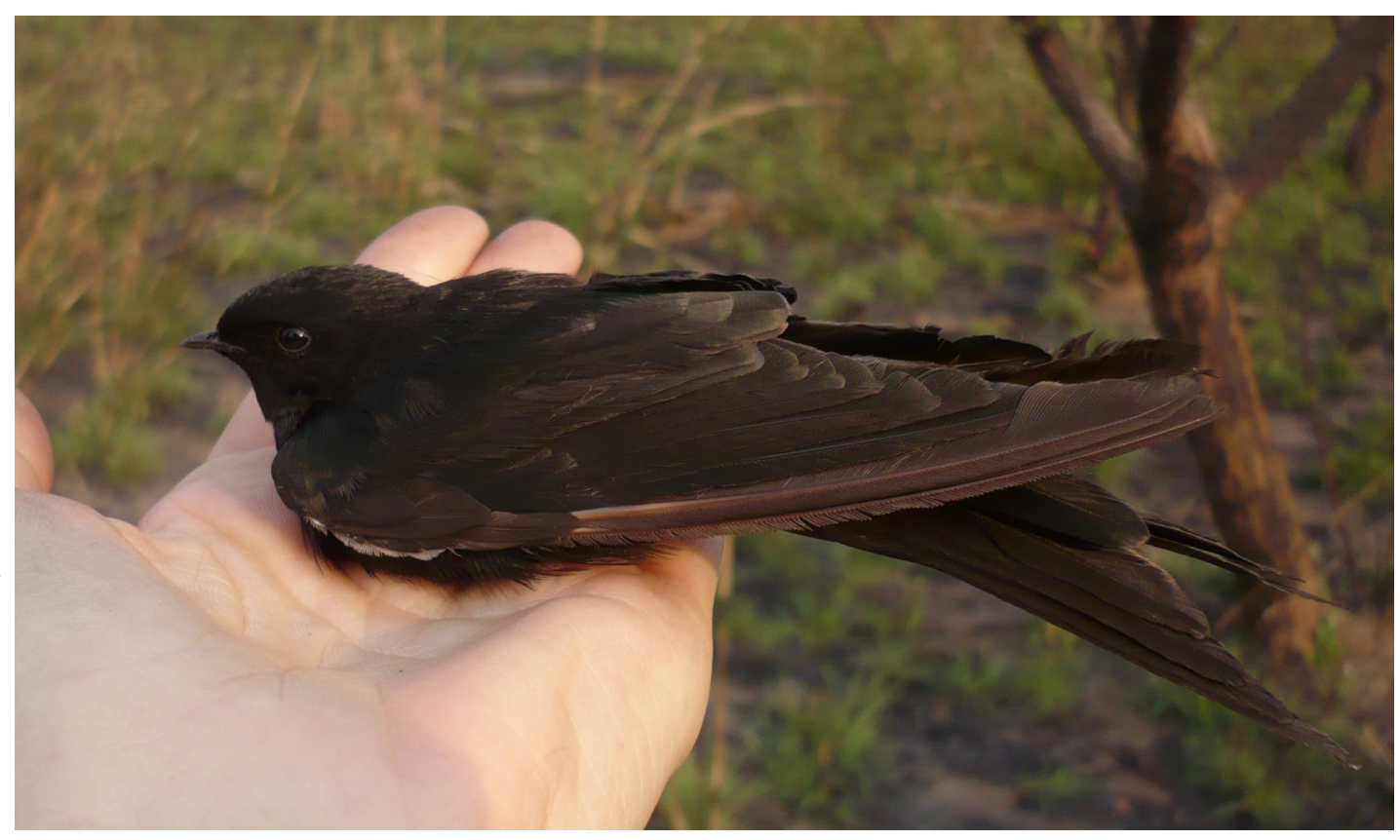

Figure 3. Releasing a Black Saw-wing Psalidoprocne pristoptera at Kissikina, Malange, Angola. The wear of the outermost flight feathers is visible in the image. 
stage 4 feathers and three old. The birds caught seemed to be in the middle of their moult at this time of the year.

Angolan Swallow Hirundo angolensis - Two birds caught, one of them in active moult with eight new feathers followed by one at stage 4 and one at stage 1 . The primary feathers of the other bird seemed to be fresh.

African Yellow Warbler Iduna natalensis - Two birds caught, one was at the end of its primary moult with nine new feathers and the outermost at stage 4 . The unmoulted feathers were more pointed at the tip and showed some wear. The different moult pattern found on the two birds caught maybe related to these birds' age as the tips of the flight feathers of the two were slightly different. The more pointed ones showed some wear whereas the more rounded ones were new. One possibility is that the bird not moulting was a juvenile.

Bubbling Cisticola Cisticola bulliens - Both birds were moulting. One already had eight new feathers and the two remaining feathers were at stage 4 . The other was only slightly behind with seven new feathers and the remaining three feathers were also at stage 4 ..

Spectacled Weaver Ploceus ocularis - Three birds were caught but none were in active moult. The flight feathers of all birds were slightly worn suggesting that moult had recently been completed. In KwaZulu-Natal, South Africa, the estimated duration of primary moult is 114 days, between February and May (Oschadleus \& Underhill 2006). The July observations are consistent with this.

Green-winged Pytilia Pytilia melba - Five birds were caught (four adults and one juvenile). All adults were in active moult. Two male birds had two new feathers and one stage 4 feather followed by seven old or one missing and six old (Figure 4). Another bird, possibly a female, was starting its moult with one new feather, another at stage 2 and the remaining eight were old. Finally, another male already

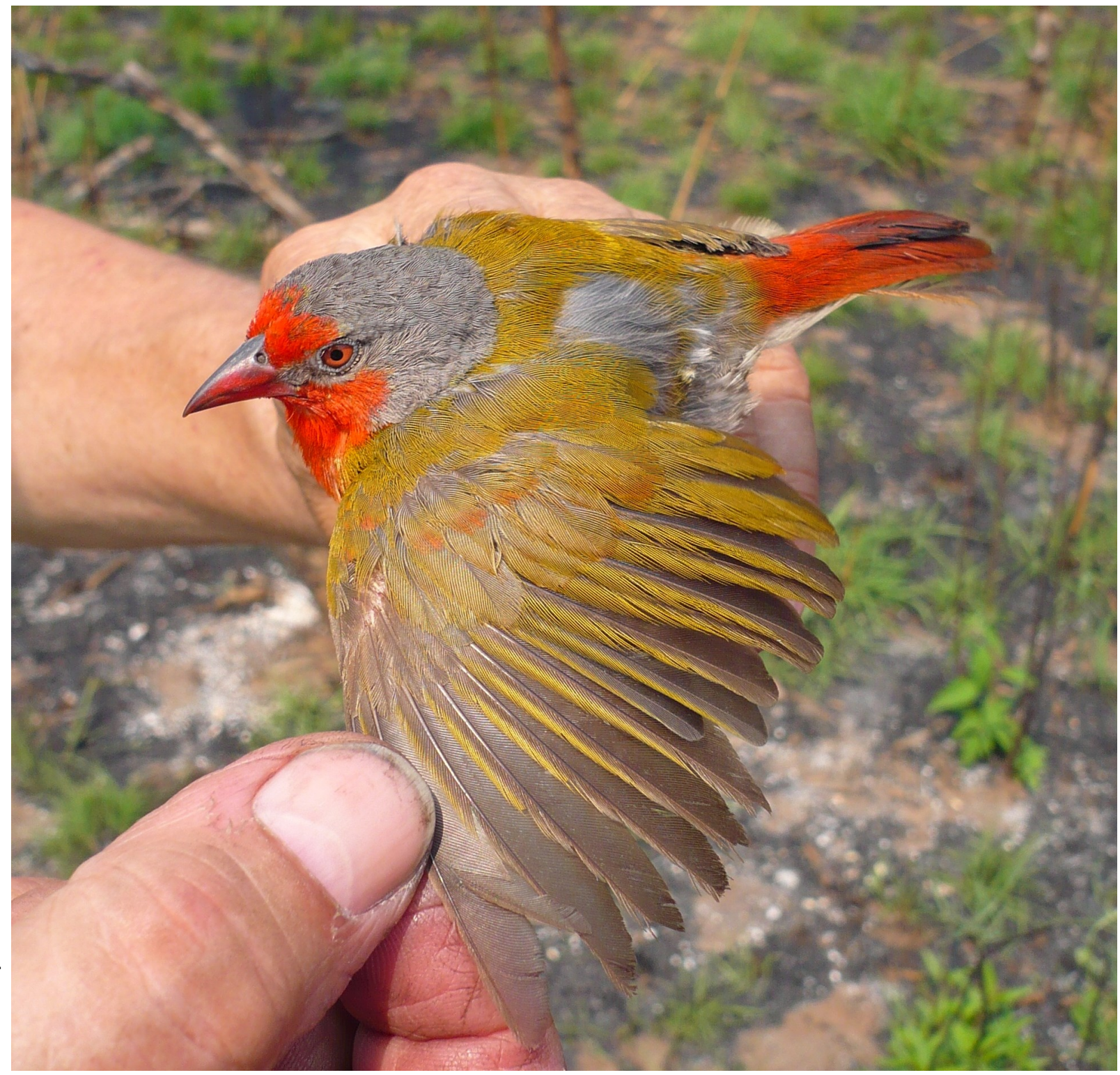

Figure 4. Adult Green-winged Pytilia Pytilia melba in moult at Kissikina, Malange, Angola.

had five new feathers followed by a stage 4 , a stage 3 and three old. The juvenile bird did not show primary moult. 
According to Bonnevie \& Oschadleus (2012), this species undertakes two complete moults each year in Botswana; one pre-breeding, in December-January, and the other post-breeding in July. The data collected in the frame of the present work corroborates the calendar for the July moult. Tyler (2001) suggests suspended and irregular moult patterns on birds of this species caught in southeast Botswana during the summer 1996/1997 and April 1998. No irregular moult was noted in the birds caught. The data suggest that moult extends is not synchronized because birds were caught in different moult stages.

\section{Jameson's Firefinch Lagonosticta rhodopareia - All five birds} caught were in active moult and they were all at the first half of primary moult with only one to three new feathers. Two birds with one new feather, one with two new feathers and two birds with three new feathers. All birds had at least 2 growing feathers. One of the birds with three new feathers was replacing the outermost feather out of the normal sequence as the four previous feathers were still old.

In Zimbabwe this finch does a complete moult in July-August while in Zambia it has a complete pre-breeding moult from October to January, according to Bonnevie and Oschadleus (2012). As all five birds caught were in active moult and all were at the first half of primary moult the timing in this part of Angola seems to be similar to that of Zimbabwe.

Orange-cheeked Waxbill Estrilda melpoda - Eight birds were caught and seven were in active moult. These were in an advanced phase of moult showing five to eight new feathers. They had new feathers followed by one feather in stage 4 , and with the old outer primaries.

\section{Acknowledgments}

During the expedition, I was hosted at the Odebrecht Angola facilities in Lauca, Malange, Angola. This research was supported by the Gabinete de Aproveitamento do Médio Kwanza (GAMEK), Angola. Our client was Envgreen, Lda. Peter Rock helped improve the English in the submitted version of this paper.

\section{References}

Bonnevie BT, Oschadleus HD 2012. Adaptations in primary wing moult of southern African Viduidae and their hosts (Estrildidae). Ostrich 83: 91-98.

Craig AJFK 1983. Moult in southern African passerine birds: a review. Ostrich 54: 220-237.

Craig AJFK, Bonnevie BT, Hulley PE, Underhill GD 2014. Primary wing-moult and site fidelity in South African mousebirds (Coliidae). Ostrich 85: 171-175.

Gill F, Wright M, Donsker D 2012. IOC world bird names (version 3.1). http://www.worldbirdnames.org.

Ginn HB, Melville DS 1983. Moult in Birds. BTO Guide No. 19. British Trust for Ornithology, Tring.

Mills M, Melo M 2013. The check list of the birds of Angola, 2013 Edition. AvesAngola, Luanda, Angola.

Moreau RE, Wilk AL, Rowan W 1948. The moult and gonad cycles of three species of birds at $5^{\circ}$ south of the equator. Proceedings of the Zoological Society of London 117: 345-364.

Oschadleus HD, Underhill LG 2006. Breeding seasonality and primary moult in weavers in eastern South Africa. Durban Museum Novitates 31: 24-31.

Rowan MK 1967. A study of the colies of southern Africa. Ostrich 32: 63-115.

Sekercioglu ÇH, Riley A 2005. A brief survey of the birds in Kumbira Forest, Gabela, Angola. Ostrich 76: 111-117.

Stresemann E, Stresemann V 1966. Die Mauser der Vogel. Journal of Ornithology 107. Sonderheft. 
Tyler SJ 2001. Moult in Scaly-feathered Finches Sporopipes squamifrons in southeast Botswana. Afring News 30: 56-59.

Verheyen R 1953. Exploration du Parc National de I'Upmba. Fascicule 19. Oiseaux. Bruxelles: Institut des Parcs Nationaux du Congo Belge.

Verheyen R 1956. Note sur l'anatomie et la classification des Coliiformes. Institut Royale des Siences Naturel De Belge 32: 1-7.

\section{Editorial acknowledgements}

Les Underhill thanks Adrian Craig for providing helpful insights and Tanya Scott for finding up-to-date references for the moult analysis of this set of tropical bird species.

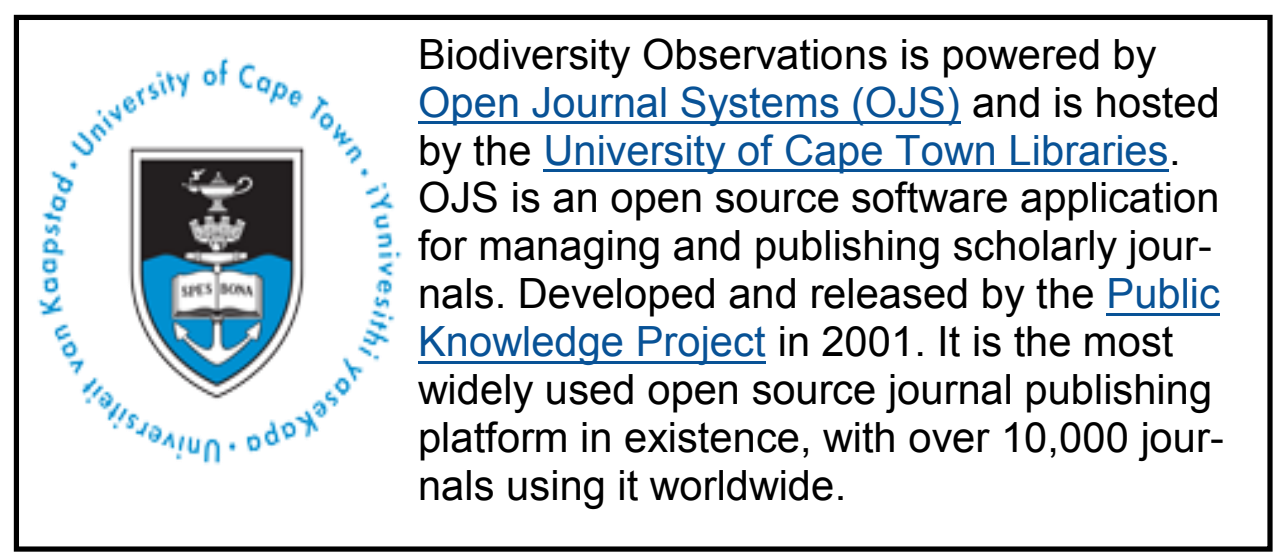

\section{Biodiversity Observations}

The scope of Biodiversity Observations includes papers describing observations about biodiversity in general, including animals, plants, algae and fungi. This includes observations of behaviour, breeding and flowering patterns, distributions and range extensions, foraging, food, movement, measurements, habitat and colouration/plumage variations. Biotic interactions such as pollination, fruit dispersal, herbivory and predation fall within the scope, as well as the use of indigenous and exotic species by humans. Observations of naturalised plants and animals will also be considered. Biodiversity Observations will also publish a variety of other interesting or relevant biodiversity material: reports of projects and conferences, annotated checklists for a site or region, specialist bibliographies, book reviews and any other appropriate material. Further details and guidelines to authors are on the journal website (https://journals.uct.ac.za/index.php/BO/).

ISSN 2219-0341

Editors: PN Laver and LG Underhill

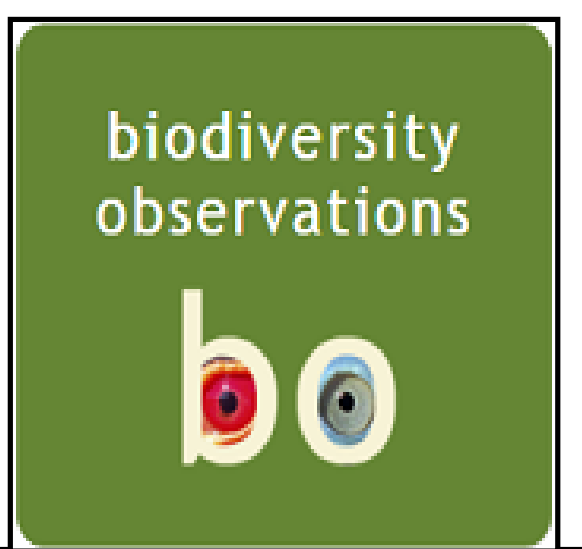

